\title{
ОРГАНІЗАЦІЯ РОБОТИ СТУДЕНТСЬКОГО НАУКОВОГО ТОВАРИСТВА В УМОВАХ ДИСТАНЦЙНОГО ФОРМАТУ ЗАБЕЗПЕЧЕННЯ ОСВІТНЬОГО ПРОЦЕСУ
}

\author{
M. O. Kozhemiaka, M. L. Golovaha, M. S. Lisunov \\ Zaporizhzhia State Medical University \\ ORGANIZATION OF THE STUDENT SCIENTIFIC SOCIETY'S WORK \\ IN THE CONDITIONS OF REMOTE FORMAT OF THE EDUCATIONAL \\ PROCESS
}

\begin{abstract}
Анотація. Пандемія COVID-19 призвела до запровадження дистанційного формату забезпечення навчального процесу в усіх галузях освіти, в тому числі й медичних закладах вищої освіти. Клінічні кафедри, особливо хірургічних дисциплін, мають певну специфіку забезпечення якісного освітнього процесу, а функціонування студентського наукового товариства $є$ його невід’ємним компонентом у контексті студентоцентрованого підходу до навчального процесу. Мета статті - продемонструвати досвід забезпечення роботи студентського наукового товариства в дистанційному форматі, визначити переваги та недоліки даного формату діяльності, окреслити головні проблеми, що потребували вирішення, та шляхи їх розв'язання, розглянути можливості використання окремих елементів дистанційного формату забезпечення роботи після завершення дії карантинних обмежень. Під час обрання платформи для забезпечення дистанційного проведення освітнього процесу необхідно враховувати можливість використання будь-яким пристроєм незалежно від встановленої операційної системи, зручний та зрозумілий інтерфейс, стабільність роботи. В якості платформи була обрана Teams від корпорації Microsoft, що зарекомендувала себе під час організації дистанційного формату забезпечення освіти. Дане середовище дозволяє безперешкодну комунікацію всіх членів наукового керівництва, обмін навчальними матеріалами, підручниками, посиланнями, аудіо- та відеофайлами, планування засідань тощо. Позитивною практикою виявилося використання матеріалів, отриманих з верифікованих колабораційних порталів та агрегаторів професійного мультимедійного контенту, де у вільному доступі наявні клінічні кейси, записи маніпуляцій та оперативних втручань (виключно моменти оперативного втручання, що мають інтерес, без рутинних етапів), хід оперативних втручань, реабілітаційні заходи тощо. Всі автори верифіковані та є фахівцями у зазначених галузях. Таким чином дистанційний формат функціонування студентського наукового товариства продемонстрував високу ефективність, окремі аспекти використання платформи для забезпечення освітнього процесу он-лайн, сторонні відкриті ресурси були визначені як позитивні практики та мають перспективу інтеграції у звичний режим роботи.
\end{abstract}

Ключові слова: студентське наукове товариство; науковий гурток; дистанційне навчання; освітній процес; програмна платформа.

Abstract. The COVID19 pandemic has led to the introduction of a distance learning format in all areas of education, including medicine. Clinical departments, especially surgical disciplines, have a specificity of educational process, and the functioning of the student scientific society is an integral part in the context of a student-centered approach to the educational process. The purpose of the article is to demonstrate the experience of providing student scientific society in remote format, identify the advantages and disadvantages of this format, outline the main problems to be solved and ways to solve them, consider the possibility of using certain elements of remote format after quarantine restrictions. A platform to provide remote educational process, must give possibility of using any device regardless of the installed operating system, be convenient and has clear interface, stability. Teams from Microsoft was chosen as the platform, which proved itself during the organization of the remote format of education. This environment allows unimpeded communication of all members of the scientific management, exchange of educational materials, textbooks, links, audio and video files, meeting planning,

() М. О. Кожем’яка, М. Л. Головаха, М. С. Лісунов 
etc. The use of materials obtained from verified collaboration portals and aggregators of professional multimedia content resource, where clinical cases, records of manipulations and surgical interventions are available (only moments of surgical intervention, without routine stages), the course of surgery, rehabilitation measures, etc, was a positive practice. All authors are verified and are experts in these areas.Thus, the remote format of the student scientific society demonstrated high efficiency, some aspects of using the platform to provide the educational process online and third-party open resources were identified as positive practices and have the prospect of integration into the usual student scientific society mode.

Key words: student scientific society; scientific club; distance learning; educational process; software platform.

Вступ. За стандартами і рекомендаціями щодо забезпечення якості в Європейському просторі вищої освіти (ESG), навчальний процес базується на студентоцентрованому підході до навчання, викладання та оцінювання. Зазначена концепція визначає здобувача освіти як суб'єкта освітнього процесу, а не об’єкт [4]. Даний підхід спрямований на стимулювання мотивації студентів, їх самоаналіз та залучення до освітнього процесу, забезпечення умов, які дозволяють розкриття творчого потенціалу здобувачів через індивідуальні, персонально обрані навчальні траєкторії. 3 метою відповідності даному критерію кафедра травматології та ортопедії Запорізького державного медичного університету (ЗДМУ) надає можливість охочим здобувачам поглиблювати свої теоретичні та практичні навички й залучає до науково-дослідницької діяльності шляхом організації діяльності студентського наукового товариства. У процесі роботи здобувачі готують доповіді, дискутують із викладачами, беруть участь у клінічних обходах, ведуть науково-дослідницьку роботу сумісно із науковими керівниками, відпрацьовують практичні навички тощо.

Пандемія COVID-19 спричинила значні зміни в забезпеченні освітньої діяльності. Згідно з Постановою Кабінету Міністрів України від 11 березня 2020 р. № 211, було заборонено відвідування закладів освіти здобувачами [3]. Головним інструментом підтримання навчального процесу в усьому світі стали різноманітні платформи, що дозволяють забезпечити дистанційний режим освіти [5, 9]. У процесі втілення дистанційної форми навчання співробітники кафедри травматології та ортопедії прийняли рішення не припиняти роботу студентського наукового товариства та гуртка, а здійснити його переведення в дистанційний формат. Вирішення потребувало одразу декілька завдань, пов’язаних із специфікою онлайн-навчання.

Мета статті - продемонструвати результати впровадження дистанційної форми роботи студентського наукового товариства клінічною кафедрою, визначити переваги та недоліки даного формату діяльності. Також визначити доцільність подібної форми забезпечення роботи гуртка на час пандемії та розглянути потенціал інтеграції елементів дистанційної форми роботи гуртка у звичний формат діяльності студентського наукового товариства після припинення дії карантинних заходів, забезпечити повноцінну самостійну роботу студентів та розкрити їх творчий потенціал, шляхом створення індивідуальних навчальних траєкторій.

Теоретична частина. У звичному форматі робота студентського наукового товариства забезпечувалась таким чином - на початку навчального року шляхом розміщення об'яв на території студентського містечка, на онлайн-ресурсах кафедри та інформування старостами здійснювалось оповіщення студентів про місце та час проведення організаційного засідання наукового гуртка. На першому засіданні шляхом відкритого голосування за більшістю голосів обирався та затверджувався староста гуртка, студенти інформувалися про формат роботи гуртка, дати проведення засідань, складався тематичний план, з урахуванням теми доповідей визначалася клінічна база, на якій відбудеться засідання, здійснювався розподіл тем доповідей між студентами. Студентів інформували про можливість долучення до практичної діяльності - чергування у травматологічному пункті, роботи в гіпсовому залі, асистенції під час оперативних втручань, надавали необхідну інформацію стосовно дозвільних документів та медичних довідок тощо. Охочі студенти обирали тему для наукової діяльності серед запропонованих або висловлювали бажання наукового пошуку за власними вподобаннями, з можливістю представлення результатів роботи у періодичних виданнях та на науково-практичних конференціях у вигляді усних, стендових доповідей тощо. Викладач, відповідальний за проведення організаційного засідання, визначав наукових керівників зазначеним студентам з урахуванням напрямку клінічної діяльності та наукового пошуку співробітників. Упродовж року, в установлені дати згідно із тематичним планом здійснювалися засідання гуртка. В обов’язки старости гуртка входив контроль процесу підготовки доповідей, за необхідності доповідачі мали змогу консультуватися у викладача, відповідального за проведення відповідного засідання. Впродовж 
року до діяльності гуртка мали змогу долучатися студенти, що виявили таке бажання, як у якості слухачів, так і у якості доповідачів. Відповідальний за інформування зазначених студентів та їх долучення до наукового товариства - староста гуртка. Під час засідання студенти презентували доповідь у вигляді усного виступу з використанням мультимедійних засобів, відповідальний викладач резюмував доповідь, доповнював та корегував інформацію, подану доповідачем, присутні мали можливість поставити запитання, дискутувати з того чи іншого приводу. Наступним етапом був клінічний обхід пацієнтів, відповідальний викладач демонстрував пацієнтів із нозологіями, що відповідають темі засідання, після повернення до навчальної аудиторії викладач демонстрував деперсоналізовані витяги з історій хвороб, рентгенологічні плівки, надавав коментарі по кожному пацієнту, викладач допомагав розв’язати проблемні питання та дати вичерпні відповіді на запитання студентів, підбивав підсумки засідання. Наприкінці навчального року підбивалися підсумки роботи наукового товариства, визначалися студенти, які презентуватимуть результати власної науково-дослідницької діяльності на щорічній студентській конференції.

У зв'язку з вимушеним переведенням на дистанційний формат роботи виник ряд перешкод та завдань, що потребували вирішення. Перш за все постало питання вибору платформи для взаємодії студентів із викладачем, яка б дозволяла як індивідуальне, так і групове обговорення, максимально наближене до реальних умов. Окрім цього, платформа повинна була забезпечувати можливість мультимедійного супроводу заняття, розміщенням додаткових матеріалів тощо. Також гостро постало питання із відсутністю практичного компонента роботи із студентами, що є принциповим моментом для хірургічної дисципліни. Робота в дистанційному форматі ускладнює демонстрацію наочних навчальних матеріалів, макетів, операційного інструментарію, ортезів та іншого устаткування, яким забезпечені навчальні аудиторії. Також дистанційний формат потребував великої кількості мультимедійних ресурсів, але забезпечення потреби в повному обсязі авторським контентом високої якості виявилося неможливим через стислі терміни переходу на дистанційний формат. Також потребувала вирішення проблема живого спілкування із пацієнтами. Ці та ряд інших проблем були вирішені в процесі організації роботи гуртка в дистанційному форматі.
Перше завдання, що потребувало вирішення, вибір платформи, на якій базуватиметься діяльність студентського наукового товариства. Після аналізу наявних середовищ, вивчення інтерфейсу та функціоналу, аналізу досвіду забезпечення освітнього процесу у періодичних виданнях, було обрано платформу Tеams від корпорації Microsoft, на якій базується забезпечення дистанційної освіти на період карантинних обмежень у ЗДМУ [1]. Зазначене середовище $є$ комплексним інструментом забезпечення дистанційної освіти, що дозволяє вирішити багато проблем, пов'язаних $з$ онлайн-форматом проведення зустрічі, та забезпечувати практичну реалізацію концепції корпоративної системи менеджменту знань [7].

Дуже вагомою перевагою зазначеного середовища $є$ широка доступність до застосування. Долучитися до освітнього процесу можливо із використанням як персонального комп’ютера, так із використанням планшета або телефона. Немає потреби в обов’язковому завантаженні додаткових застосунків, використання можливе у будь-якому браузері, встановленому на пристрої. За бажанням користувача, можливе завантаження та встановлення застосунку, що дещо спрощує роботу та відкриває доступ до певного функціоналу, але не є необхідним для використання функцій, необхідних для забезпечення освітнього процесу. Розроблено застосунок для операційної системи Windows, IOs, Android як для стаціонарних пристроїв, так і для мобільних гаджетів. Тому для роботи із платформою здобувач потребує лише пристрою та доступу до глобальної мережі «Інтернет». Інтерфейс платформи MS Tеams відзначається інтуїтивною зрозумілістю, та не викликає складнощів з використанням як студентами, так і викладачами. Для зручності роботи середовище передбачає об’єднання певного кола користувачів у команди, та спільну роботу впродовж тривалого проміжку часу. Під час перегляду загального каналу в команді користувач бачить заплановані зустрічі, повідомлення від керівників (завідувача та завуча кафедри, відповідальних за проведення окремих засідань викладачів, старости гуртка тощо), розміщені посилання на сторонні ресурси, фото-, відео-, аудіоматеріали тощо. Будь-Хто із здобувачів може залишити повідомлення або поставити запитання як у загальному каналі команди, так і у приватному чаті із співробітниками кафедри. Наведений вище функціонал повністю вирішує питання із неможливістю особистої зустрічі здобувача із викладачем. Окрім того, даний формат 
зв’язку більш гнучкий, оскільки запитання може бути поставлене в будь-який момент, навіть у неробочий час, не порушуючи особистий простір та приватне життя викладача, який у свою чергу має змогу відповісти у зручний для себе час.

Також у команді наявний канал із файловим менеджером, що дозволяє співробітникам кафедри розміщувати актуальні та необхідні для студентів матеріали: тематичний план та розклад роботи гуртка, теоретичні матеріали для самопідготовки, навчальні відеофільми тощо. Даний функціонал значно спрощує обмін матеріалами, оскільки немає необхідності розповсюджувати документи електронною поштою, старостою гуртка тощо. Усі здобувачі мають рівнозначний та постійний доступ з будьякого пристрою до всіх розміщених матеріалів.

Безпосередньо забезпечення роботи гуртка відбувається у форматі онлайн-зборів, що максимально наближені до реальних умов. Наявна можливість аудіо- та відеозв’язку. Інтерфейс програми дозволяє за потребою вмикати та вимикати мікрофон і камеру кожному користувачу. Керівник зборів може керувати роботою мікрофонів усіх присутніх. Тому створюються комфортні умови для спілкування та ведення дискусії, рівень шумів і перешкод незначний. У загальному каналі команди відповідальний викладач або староста гуртка має змогу запланувати зустріч заздалегідь, усі користувачі команди отримають сповіщення, та зможуть спланувати свій час.
Час проведення засідань призначався з урахуванням освітнього процесу в дистанційному форматі.

Невід'ємною частиною засідання гуртка є доповідь студентів та їі наступний аналіз викладачем. Інтерфейс середовища дозволяє здійснювати мультимедійний супровід завдяки повній інтеграції програмного забезпечення Power Point у даній платформі (рис. 1). Доповідач має змогу самостійно завантажити презентацію та керувати її переглядом. Під час доповіді всі користувачі перебувають із вимкненими мікрофонами, що унеможливлює створення шуму та перешкод. Усі питання, які виникають, присутні на засіданні мають змогу написати в чат зборів, при цьому не заважаючи доповідачу. Після завершення доповіді бажаючі поставити запитання мають змогу «підняти руку» - окрема опція даного середовища, керівник зборів бачить даних користувачів та почергово надає слово. Даний порядок проведення дозволяє впорядкувати виступ та обговорення, уникнути безладу та надати кожному можливість взяти участь у дискусії та бути почутим.

Наступним етапом проведення засідання є відвідування пацієнтів стаціонару, що мають нозологію, відповідну до теми засідання (рис. 2). Заздалегідь перед початком засідання викладач, що, як вже зазначалось, є практикуючим лікарем, обирає пацієнта та отримує письмову згоду на участь у клінічному обході із застосуванням засобів аудіо- та відеозапису. Під час засідання викладач веде бесіду

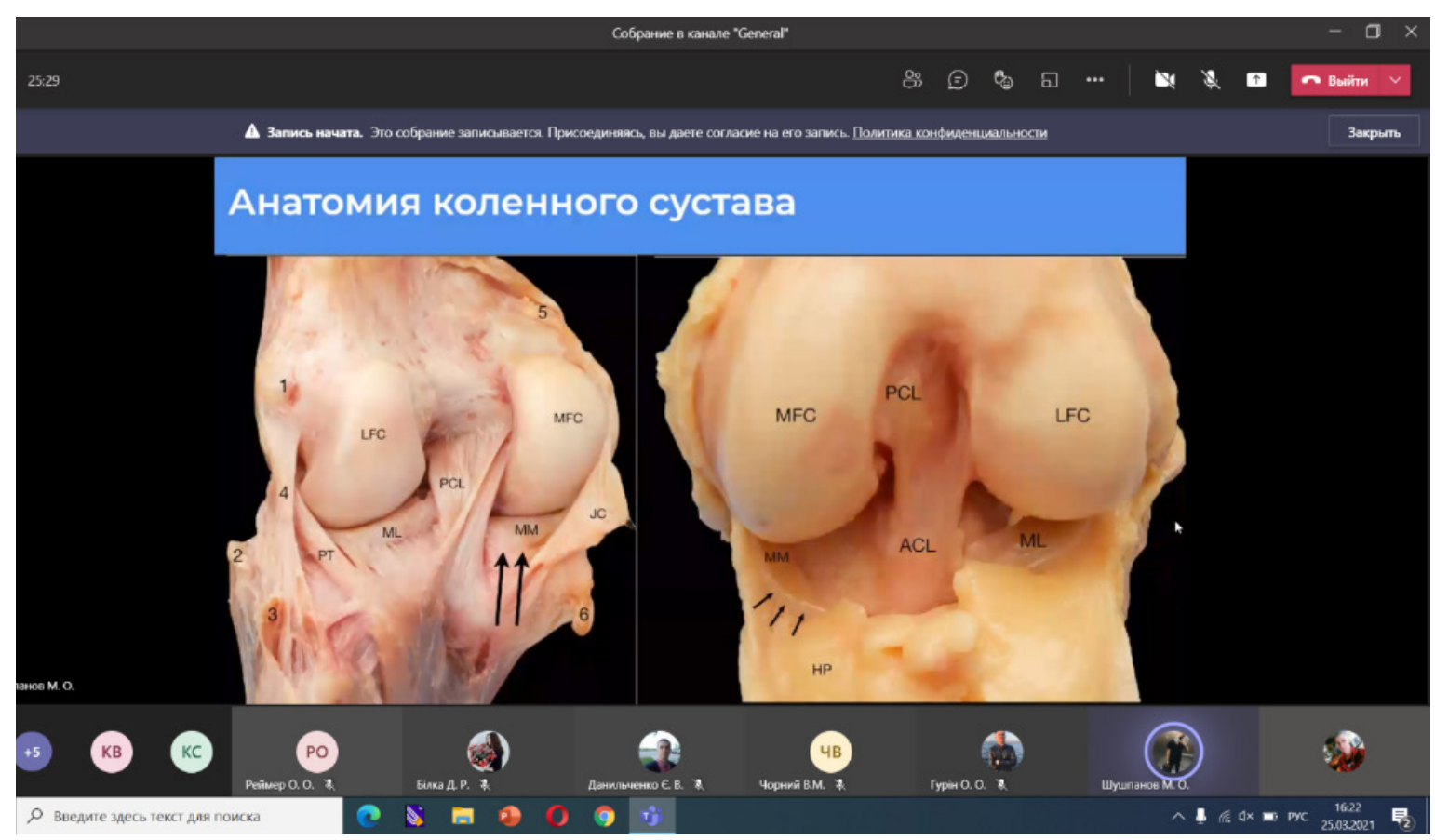

Рис. 1. Вигляд демонстрації мультимедійного супроводу доповіді. 
із пацієнтом, здійснює клінічний огляд з урахуванням етичних та деонтологічних норм. Учасники засідання мають змогу поставити пацієнту запитання та вступити з ним у бесіду. Після завершення об- ходу викладач повертається до кабінету, має змогу завантажити в чат засідання деперсоналізовані дані історії хвороби, рентгенограми тощо та обговорити із учасниками засідання даний клінічний випадок.

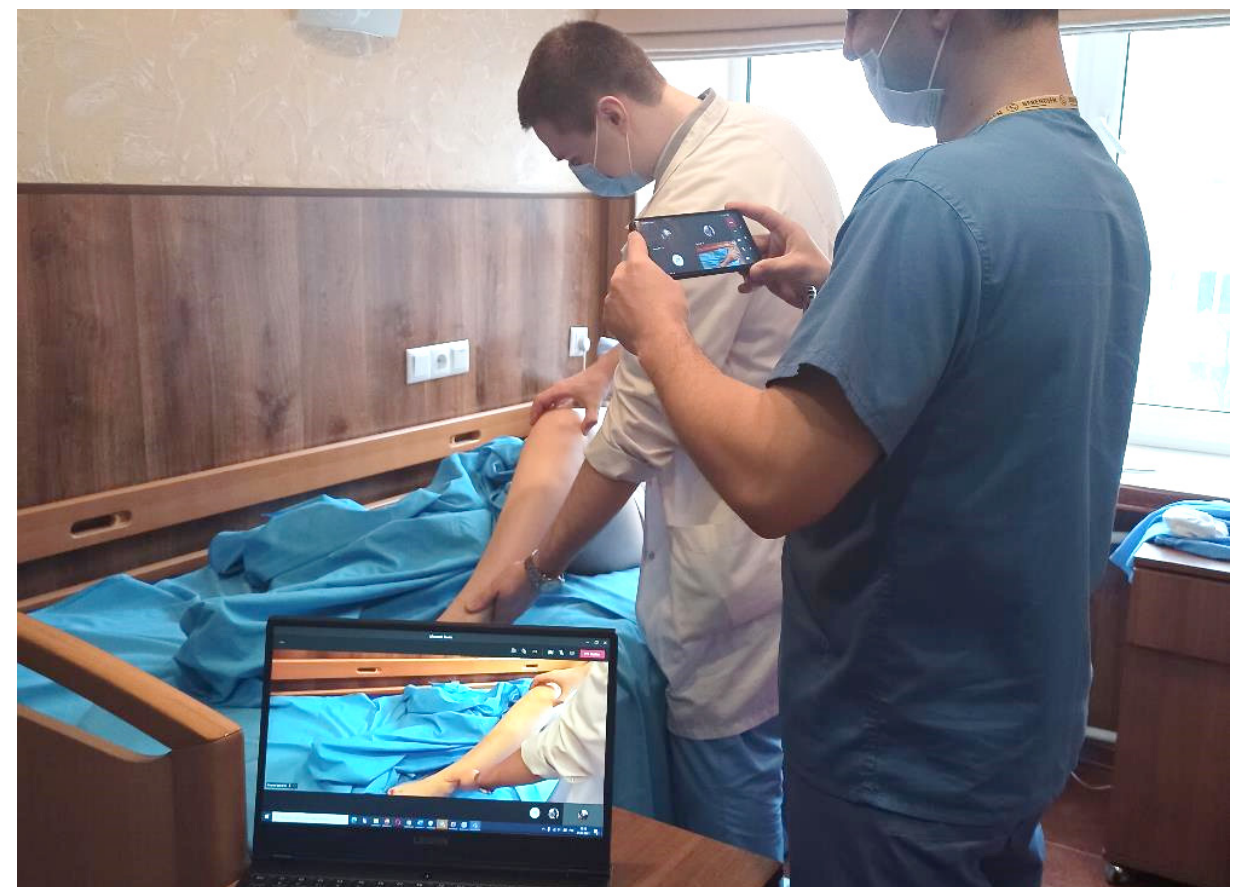

Рис. 2. Вигляд онлайн-демонстрації клінічного обстеження пацієнта.

Таким чином, повне застосування функціоналу платформи MS Teams дозволяє вирішити більшість проблем дистанційного навчання, а у певних питаннях і полегшити забезпечення функціонування наукового товариства.

Невирішеним залишається лише питання практичного компонента діяльності студентського наукового товариства. На період карантинних обмежень перебування на клінічних базах кафедри осіб, безпосередньо не пов'язаних із лікувальним процесом, категорично заборонено, що унеможливлює чергування, асистенції та участь у маніпуляціях. Від застосування засобів відеозв’язку під час проведення оперативних втручань та маніпуляцій відмовились, оскільки час, відведений на засідання, нераціонально використовувати на повний перегляд операції з усіма рутинними її компонентами, що не мають інтересу для перегляду. До того ж мають місце певні складнощі, пов'язані $з$ деонтологічними та морально-етичними питаннями. I врешті-решт, час проведення засідання майже унеможливлює вірогідність проведення в цей момент оперативного втручання або маніпуляції за темою засідання. В якості вирішення даного питання учасникам студентського наукового това- риства були запропоновані власні матеріали кафедри, а також матеріали, отримані з верифікованих колабораційних порталів та агрегаторів професійного мультимедійного контенту, на кшталт порталів vumedi, orthobullets, radiopedia, Touch Surgery й інших, де у вільному доступі наявні клінічні кейси, записи маніпуляцій та оперативних втручань (виключно моменти оперативного втручання, що мають інтерес, без рутинних етапів), ходу оперативних втручань, реабілітаційних заходів тощо [6, 8]. Всі автори верифіковані та є фахівцями у зазначених галузях. Учасникам СНТ пропонуються тематичні до наступного засідання відеоматеріали, що завантажуються у файли команди та наявні у необмеженому, вільному доступі. Питання, що виникають, обговорюються на засіданні гуртка. Окремі матеріали, що викликали зацікавленість, відповідальний викладач має змогу увімкнути безпосередньо під час засідання, пояснювати у режимі он-лайн, за потреби зупиняти відео, з метою внесення коментарів та роз'яснень. Варто відзначити, що настільки детальний розбір оперативного втручання неможливий в умовах реальної присутності студентів в операційній, оскільки кількість осіб, що можуть перебувати під час втручання, обмежена 
санітарно-епідемічними нормами, хірург не може відволікатися від втручання на надання коментарів та ведення дискусії, спостерігачі й, у певних випадках, асистенти не мають змоги спостерігати за втручанням у повному обсязі через віддаленість від операційної рани. До того ж виконання оперативного втручання з приводу цікавого клінічного випадку, що здебільшого й має інтерес серед учасників студентського наукового товариства, не завжди збігається із присутністю здобувача в клініці, на відміну від відеофайла, до якого здобувачі мають необмежений доступ.

Під час розбору оперативних втручань з верифікованих колабораційних порталів та агрегаторів професійного мультимедійного контенту виявилось, що здобувачі мають складнощі із комплексним розумінням показань до певного виду оперативного втручання, етапів оперативного втручання та післяопераційного піклування. На сьогодні дуже мало літератури, що давала б вичерпні відповіді на наведені вище запитання. Тому у якості посібника учасникам СНТ запропоновано використання ресурсу AO Surgery Reference. Це інтерактивна платформа, що містить актуальну до сучасних досліджень інформацію стосовно класифікації переломів, показань та протипоказань до того чи іншого методу оперативного лікування, повний хід оперативного втручання, починаючи від укладки хворого до накладання швів, реабілітаційні заходи тощо. Інформація збагачена якісним авторським ілюстративним матеріалом, у більшості рубрик є відеоматеріали з використанням макетів та здійснення описаного оперативного втручання на ньому із використанням реального інструментарію, що полегшує розуміння та сприйняття інформації.

Висновки та перспективи подальших досліджень. Отриманий досвід роботи студентського наукового товариства в дистанційному форматі свідчить про високу ефективність та результативність, наближену до реальних зустрічей. За умови повного використання запропонованого функціоналу платформ для забезпечення дистанційного навчання та застосування сторонніх ресурсів можна реалізувати всі задачі діяльності студентського наукового товариства. Головним недоліком дистанційної форми є відсутність живого спілкування, контакту здобувача із викладачем, живої дискусії в аудиторії. Застосування відеозв’язку дозволило частково вирішити цю проблему, забезпечивши повноцінний обмін інформацією, ведення конструктивної бесіди. Серед переваг слід відзначити, що вдалося збільши- ти кількість присутніх студентів, після проведення опитування виявилось, що віддаленість клінічних баз та час проведення засідань у деяких випадках збігаються із роботою певного числа здобувачів та унеможливлюють їх присутність, дистанційний формат дозволяє їм долучитися до засідання. Відсутність практичного компонента вдалося частково вирішити шляхом застосування сторонніх ресурсів із навчальними відеоматеріалами оперативних втручань, маніпуляцій та ресурсами із покроковим ілюструванням методики оперативних втручань, реабілітації тощо. Але, звісно, повністю замінити практичний компонент підготовки на клінічній дисципліні хірургічного спрямування неможливо. Отже, після покращення епідеміологічної обстановки та зняття карантинних обмежень кафедра травматології та ортопедії ЗДМУ націлена на повернення звичного формату роботи гуртка та наукового товариства, але розглядається можливість та планується спроба інтеграції окремих компонентів дистанційного формату. Відзначається зручність об’єднання всіх здобувачів в одну команду в MS Teams, що значно спрощує інформування учасників СНТ стосовно діяльності гуртка. Також викладачі та здобувачі відзначають зручність розміщення у команді навчальних посібників, підручників, книжок, посилань й інших матеріалів, що дає можливість отримати необмежений доступ одразу всім учасникам СНТ. Розглядається можливість проведення гібридних засідань із присутністю учасників CHT та онлайн-трансляцією на платформі MS Teams із метою надання можливості дистанційної присутності студентам, які через трудову або особисту зайнятість не змогли з’явитися на зібрання особисто. Використання верифікованих колабораційних порталів та агрегаторів професійного мультимедійного контенту продемонструвало добрі результати та наочність, позитивно оцінено здобувачами та буде використовуватися й у подальшому.

Таким чином, період дистанційного навчання та роботи студентського наукового товариства дозволив по-новому оцінити можливості використання платформ для забезпечення онлайн-освіти, визначити недоліки даного формату забезпечення освітнього процесу та переваги, відокремити позитивні компоненти, що можуть бути інтегровані у звичний формат діяльності. В подальшому плануються робота за даним напрямом та аналіз результатів впровадження позитивних практик дистанційного формату діяльності у звичний режим роботи гуртка. 


\section{Список літератури}

1. Головаха М. Л. Особливості підготовки студентів медичного напряму при вивченні дисципліни «Травматологія та ортопедія» за умов дистанційного навчання / М. Л. Головаха, М. О. Кожем'яка, Б. А. Кузнєцов // Всеукраїнський науково-практичний журнал «Директор школи, ліцею, гімназії». Спеціальний випуск «Вища освіта України у контексті інтеграції до європейського освітнього простору». - 2021. - Т. I (86), № 2. - С. 143 155.

2. Концепція корпоративної системи менеджменту знань Запорізького державного медичного університету / Ю. М. Колесник, М. О. Авраменко, С. А. Моргунцова [та ін.] // Медична освіта. - 2019. - № 3. - С. 51-54.

3. Про запобігання поширенню на території України коронавірусу COVID-19 : Постанова Кабінету Міністрів України від 11.03.2020 р. № 211 // Офіційний вісник України. - 2020. - № 23. - Ст. 896.

\section{References}

1. Holovakha, M.L., Kozhemiaka, M.O., \& Kuznietsov, B.A. (2021). Osoblyvosti pidhotovky studentiv medychnoho napriamu pry vyvchenni dystsypliny «Travmatolohiia ta ortopediia» za umov dystantsiinoho navchannia [Peculiarities of medical students trainig in the study of the discipline "traumatology and orthopedics" under distance learning]. Vseukrainskyi naukovo-praktychnyi zhurnal «Dyrektor shkoly, litseiu, himnazii». Spetsialnyi vypusk «Vyshcha osvita Ukrainy u konteksti intehratsii do yevropeiskoho osvitnoho prostoru» - All Ukrainian Scientific-Practical Magazine "Principal of School Liceum Gymnasium”. Special Thematic Issue "Higher Education of Ukraine in the Cpntext of Intergration into the European Educational Space”, I (86) (2), 143-155 [in Ukrainian].

2. Kolesnyk, Y.M., Avramenko, M.O., Morhuntsova, S.A., Ryzhov, O.A., \& Ivankova, N.A. (2019). Kontseptsiia korporatyvnoi systemy menedzhmentu znan zaporizkoho derzhavnoho medychnoho universytetu [The concept of the corporate knowledge management system of zaporizhzhia state medical university]. Medychna osvita - Medical Education, 3, 51-54 [in Ukrainian].

3. Postanova Kabinetu Ministriv Ukrainy Pro zapobihannia poshyrenniu na terytorii Ukrainy koronavirusu COVID-19 vid 11.03.2020 r. № 211 [Resolution of the Cabinet of
4. Стандарти і рекомендації щодо забезпечення якості в Європейському просторі вищої освіти (ESG). - K. : ТОВ «ЦС», 2015. - 32 с.

5. Coping With COVID-19 / J. A. Lieberman, T. Nester, B. Emrich [et al.] // American Journal of Clinical Pathology. - 2021. - Vol. 155, Issue 1. - P. 79-86.

6. Giverts Roman. VuMedi [Electronic resource] / Roman Giverts. - Access mode : https://www.vumedi.com/.

7. Microsoft. MS Teams [Electronic resource] / Microsoft. - Access mode : https://teams.microsoft.com/.

8. Nehme Jean. Touch Surgery [Electronic resource] / Jean Nehme, Dr Andre Chow. - Access mode : https://www. touchsurgery.com/.

9. Pre-clinical remote undergraduate medical education during the COVID-19 pandemic: A survey study / B. Shahrvini, S. L. Baxter, C. S. Coffey [et al.] // BMC Medical Education. - 2021. - Vol. 21, Issue 1. - P. 13.

Ministers of Ukraine On Prevention of the Spread of Coronavirus COVID-19 on the Territory of Ukraine dated March 112020 No. 211]. Ofitsiinyi visnyk Ukrainy - Official Bulletin of Ukraine, 23, 896 [in Ukrainian].

4. (2015). Standarty i rekomendatsii shchodo zabezpechennia yakosti $v$ Yevropeiskomu prostori vyshchoi osvity (ESG) [Standards and recommendations for quality assurance in the European Higher Education Area (ESG)]. Kyiv: CS Ltd. [in Ukrainian].

5. Lieberman, J.A., Nester, T., Emrich, B., Staley, E.M., Bourassa, L.A., \& Tsang, H.C. (2021). Coping With COVID-19. American Journal of Clinical Pathology, 155 (1), 79-86. https://doi.org/10.1093/ajcp/aqaa152.

6. Giverts, R. (2021). VuMedi. Retrieved from: https:// www.vumedi.com/.

7. Microsoft (2021). Checking your credentials. . . MS Teams. Retrieved from: https://teams.microsoft.com/.

8. Nehme, J., \& Chow, A. (2021). Touch Surgery. Retrieved from: http://www.touchsurgery.com/.

9. Shahrvini, B., Baxter, S.L., Coffey, C.S., MacDonald, B.V., \& Lander, L. (2021). Pre-clinical remote undergraduate medical education during the COVID-19 pandemic: A survey study. BMC Medical Education, 21(1), 13. https://doi.org/10.1186/s12909-020-02445-2. 